\title{
Mapping vegetation communities of the Karkonosze National Park using APEX hyperspectral data and Support Vector Machines
}

\section{Abstract}

This research aims to discover the potential of hyperspectral remote sensing data for mapping mountain vegetation ecosystems. First, the importance of mountain ecosystems to the global system should be stressed due to mountainous ecosystems forming a very sensitive indicator of global climate change. Furthermore, a variety of biotic and abiotic factors influence the spatial distribution of vegetation in the mountains, producing a diverse mosaic leading to high biodiversity.

The research area covers the Szrenica Mount region on the border between Poland and the Czech Republic - the most important part of the Western Karkonosze and one of the main areas in the Karkonosze National Park (M\&B Reserve of the UNESCO).

The APEX hyperspectral data that was classified in this study was acquired on 10th September 2012 by the German Aerospace Center (DLR) in the framework of the EUFAR HyMountEcos project. This airborne scanner is a 288 -channel imaging spectrometer operating in the wavelength range $0.4-2.5 \mu \mathrm{m}$.

For reference patterns of forest and non-forest vegetation, maps (provided by the Polish Karkonosze National Park) were chosen. Terrain recognition was based on field walks with a Trimble GeoXT GPS receiver. It allowed test and validation dominant polygons of 15 classes of vegetation communities to be selected, which were used in the Support Vector Machines (SVM) classification. The SVM classifier is a type of machine used for pattern recognition. The result is a post classification map with statistics (total, user, producer accuracies, kappa coefficient and error matrix). Assessment of the statistics shows that almost all the classes were properly recognised, excluding the fern community. The overall classification accuracy is $79.13 \%$ and the kappa coefficient is 0.77 . This shows that hyperspectral images and remote sensing methods can be support tools for the identification of the dominant plant communities of mountain areas.

Keywords

Hyperspectral data $\cdot$ APEX $•$ Karkonosze National Park

- mapping/ classification • vegetation communities

(C) University of Warsaw - Faculty of Geography and Regional Studies

\author{
Adriana Marcinkowska ${ }^{1}$ \\ Bogdan Zagajewski \\ Adrian Ochtyra ${ }^{3}$ \\ Anna Jarocińska ${ }^{4}$ \\ Edwin Raczko \\ Lucie Kupková \\ Premysl Stych ${ }^{7}$ \\ Koen Meuleman
}

'Department of Geoinformatics and Remote Sensing

Faculty of Geography and Regional Studies,

University of Warsaw

e-mail: adriana.marcinkowska@student.uw.edu.pl

2Department of Geoinformatics and Remote Sensing

Faculty of Geography and Regional Studies,

University of Warsaw

e-mail: bogdan@uw.edu.pl

${ }^{3}$ College of Inter-Faculty Individual Studies

in Mathematics and Natural Sciences

University of Warsaw

Department of Geoinformatics and Remote Sensing

Faculty of Geography and Regional Studies,

University of Warsaw

e-mail: adrian.ochtyra@uw.edu.pl

${ }^{4}$ Department of Geoinformatics and Remote Sensing

Faculty of Geography and Regional Studies,

University of Warsaw

e-mail: ajarocinska@uw.edu.pl

${ }^{5}$ Department of Geoinformatics and Remote Sensing

Faculty of Geography and Regional Studies,

University of Warsaw

e-mail: edwin.raczko@student.uw.edu.pl

${ }^{6}$ Department of Applied

Geoinformatics and Cartography

Faculty of Science

Charles University in Prague

e-mail: lucie.kupkova@gmail.com

'Department of Applied

Geoinformatics and Cartography

Faculty of Science

Charles University in Prague

e-mail: stych@natur.cuni.cz

${ }^{8} \mathrm{VITO}$ - Centre for Remote Sensing and Earth Observation

Processes

e-mail: koen.meuleman@vito.be

Received: 3 September 2013

Accepted: 30 December 2013

\section{Introduction}

Mountainous ecosystems with plant communities are very sensitive indicator of global climate change and should be monitored. On the other hand, the variety of biotic and abiotic factors influencing the spatial distribution of vegetation is the product of a diverse mosaic of habitats leading to high biodiversity. This should be analysed in highly protected areas and this information can be used for the suitable management of national parks. 
Mountain plant species have developed specific adaptations to survive the harsh conditions of life in variable habitats (low temperatures, high radiation, strong and cold winds and short vegetation period). Specific adaptations can be observed as different relationships between leaf characteristics, such as green and red pigment content, plant tissue structure, waxes, cuticles, etc. All of them have a direct impact on reflectance which can be measured and quantified using hyperspectral sensors and their products (high spectral resolution imagery). Hyperspectral data or imaging spectrometry can be described as the acquisition of images in hundreds of contiguous, registered, spectral bands, such that for each pixel a radiance spectrum can be derived (Goetz 2009). The application of remote sensing, especially hyperspectral remote sensing techniques, allows vegetation research and mapping (Zagajewski \& Sobczak 2003; Zagajewski 2010).

\section{Background}

One of the first studies based on the spectral characteristics of plant communities in mountains areas was conducted by the U.S. Geological Survey in 2003 (Kokaly et al. 2003). The authors acquired the spectral characteristics of the dominant plant communities in the Yellowstone National Park and hyperspectral imagery from an AVIRIS ${ }^{1}$ scanner. The AVIRIS data allowed forest and nonforest vegetation maps of the park to be created, analyzing 38 communities using spectral characteristics. The overall accuracy of classification was $74.1 \%$, the kappa coefficient 0.62 (Kokaly et al. 2003). An interesting study was also carried out in the framework of the Nature 2000 area - Kalmthoutse Heide in Belgium (Delalieux et al. 2010). Based on field mapping and $\mathrm{AHS}^{2}$ hyperspectral imagery using the Spectral Unmixing and decision tree methods, 27 vegetation types were classified. The total accuracy of the classification was $84 \%$, and the kappa index 0.79. Angular hyperspectral CHRIS/Proba images and 3 classifiers: Random Forest (RF), Adaboost and Support Vector Machines (SVM), were carried out in the framework of the heathland Nature 2000 area in Belgium. Molinia-encroached heath reached an accuracy of $75-80 \%$ (Chan et al. 2012). Hyperspectral images were also used for classifying the wetland plant communities of the southern part of Ontario, Canada (Jollineau \& Howarth 2008). The authors acquired spectrally pure pixels from the $\mathrm{CASI}^{3}$ data for classification purposes. For classification two methods were chosen: Spectral Angle Mapper and Maximum Likelihood. For the 10 vegetation types used in this research, the overall accuracy was $92 \%$. Furthermore, very good results in the classification of plant communities have been achieved during research in the Tatra Mountains in Poland (Zagajewski 2010; Zagajewski et al. 2005). Based on 79 spectral bands of DAIS $7915^{4}$ hyperspectral imagery, 38 vegetation communities were classified. The overall accuracy was $89.6 \%$, kappa coefficient 0.86 . Hyperspectral data are also widely used for the analysis of agriculture (Olesiuk et al. 2009). Based on HyMAP data ${ }^{5}$, seven crops in the Demmin (northeast Germany) area were classified. In this research, a SNNS ${ }^{6}$ simulator was used as the classification method. For better results HyMAP data were combined with vegetation indices. The overall classification accuracy reached $92.5 \%$, while the kappa coefficient was 0.91

Very good classification results based on hyperspectral data were achieved using a Support Vector Machines classifier. A comparative research project of 4 land cover classification

\footnotetext{
${ }^{1224}$ spectral bands, spatial resolution 2-20 m

263 spectral bands, spatial resolution $2.4 \mathrm{~m}$

${ }^{3} 288$ spectral bands, spatial resolution $4 \mathrm{~m}$.

${ }^{4} 79$ spectral bands, spatial resolution $5-20 \mathrm{~m}$.

${ }^{5} 126$ spectral bands, spatial resolution 3-10 m.

${ }^{6}$ Stutgart Neural Network Simulator.
}

methods: maximum likelihood, decision tree, neural network and SVM (Pal \& Mather 2004) was conducted on DAIS 7915 data of the La Mancha region in central Spain. Different numbers of spectral bands (ranging from 5 to 65) and two data sets used for training composed of 100 and 500 pixels per class respectively were chosen to classify 9 forms of land cover. The best result was achieved with the SVM classifier which used the largest number of bands and training data per class in the process $(65$ and 500 pixels for two data sets) - the accuracy was $97.5 \%$. Another example is a classification of forest areas based on the fusion of hyperspectral (AISA Eagle ${ }^{7}$ ) and LiDAR data using SVM, Gaussian maximum likelihood and k-NN techniques (Dalponte et al. 2008). Different numbers of spectral bands (25-126) were chosen to classify 19 classes of tree species in a complex forest scene covering the "Bosco della Fontana" nature reserve in the Po Plain near the city of Mantua (Italy). The authors pointed out that a higher accuracy was reached for SVM using all AISA bands (kappa coefficient: 0.89). Incorporation of LiDAR data generally improved the classification performance. SVM is more efficient than typical neural networks in terms of accuracy, simplicity and robustness, not to mention its speed (Camps-Valls et al. 2004). This method was used for the classification of six classes of crops in the area of Barrax (Spain) based on HyMAP images. For each class user, the accuracy for SVM was over $90 \%$, while the producer accuracy was $>84 \%$ (Camps-Valls et al. 2004). Based on AVIRIS data vegetation classification of the northern part of Indiana (Gualtieri \& Cromp 1998) was also performed. The SVM algorithm was used for the analysis and then compared with the method labeled bLOOC+DAFE+ECHO and the Euclidean classification. For a 4 class subset scene and a 16 class full scene the best results were obtained for SVM, with a performance of $95.9 \%$ (4 classes) and $87.3 \%$ (16 classes).

\section{Study area}

The study area was located in the western part of the Karkonosze National Park, covering the Szrenica Mount (Figure 1)

The vegetation of this part of the Park is well recognized and mapped by the team of Prof. B. Wojtun, Prof. L. Zolnierz and Dr. A. Raj (2004). The map of current vegetation of the western Polish Karkonosze National Park contains 14 forest and nonforest communities starting from areas without vegetation, lichens, mountain meadows, shrubs and natural forest areas (Woitun et al., 2004). This map was provided by the National Park for this study and was used as a background layer for the Trimble GeoXT GPS receiver during the terrain selection of testing and validating polygons for classification and post classification procedures (statistical accuracy assessment of the SVM classification).

\section{Data}

The Airborne Prism Experiment (APEX) hyperspectral imager consists of 288 spectral bands (acquiring in the spectral range $0.3937-2.4673 \mu \mathrm{m})$. The images have very high radiometric, spectral and spatial resolution (up to $1.75 \mathrm{~m}$.). The APEX scanner can be used in a broad range of scientific and administrative organizations and is useful in many areas of science, for example in ecology, limnology, geology, atmospheric sciences, natural hazards, disaster management and the detection of different materials (Itten et al. 2008). Data from this scanner can also be used for very accurate identification of vegetation.

The APEX data used for this study was acquired on 10th September 2012 by the VITO (Flemish Institute for Technological Research) APEX team, during a flight campaign realized in the framework of the HyMountEcos (Hyperspectral Remote

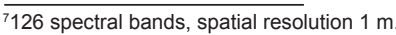




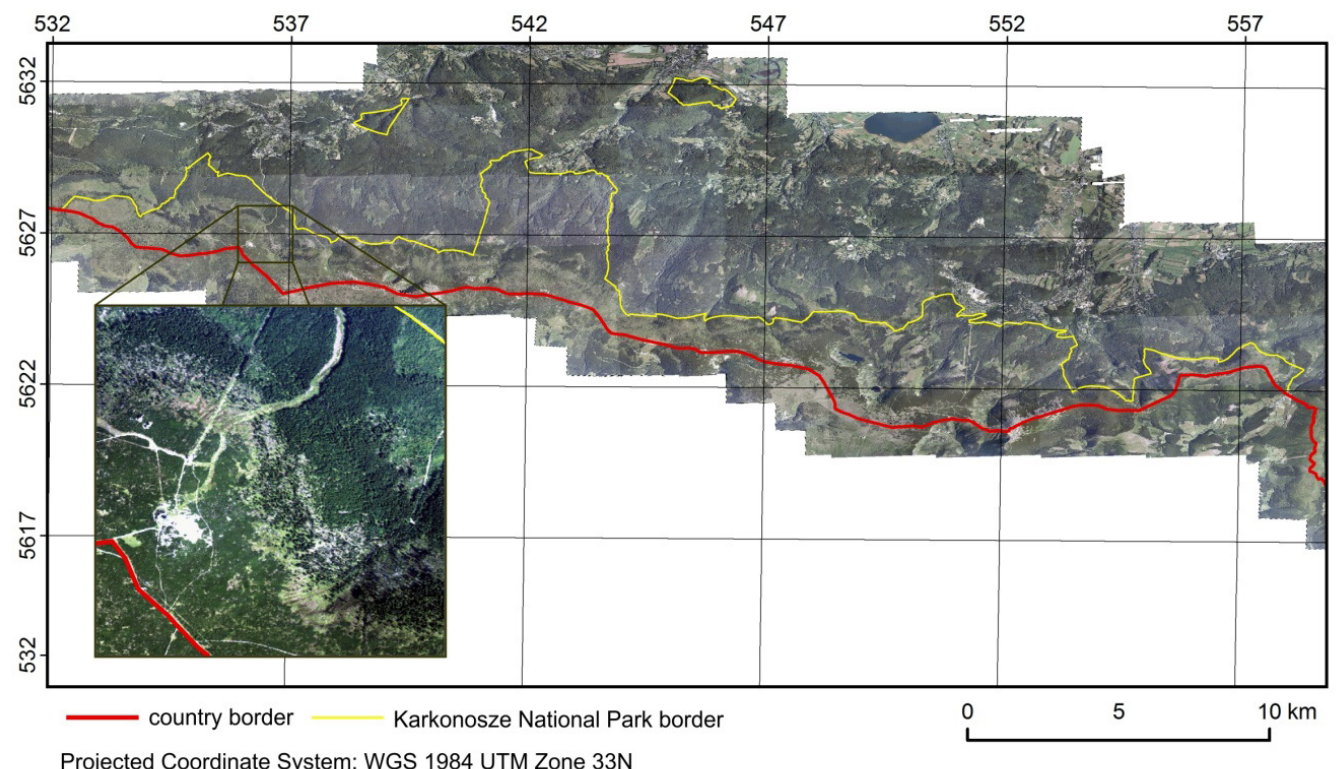

Projected Coordinate System: WGS 1984 UTM Zone 33N Projection: Transverse Mercator

Figure 1. The Szrenica Mount area in the Karkonosze National Park

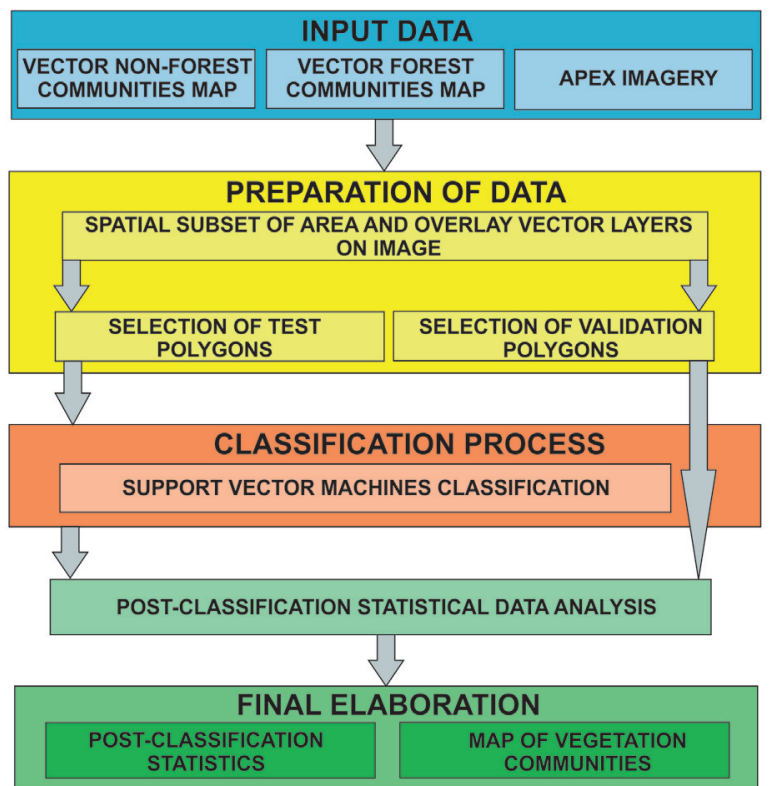

Figure 2. The classification scheme

Sensing for Mountains Ecosystems) project. APEX was installed onboard a Dornier 228 operated by DLR Braunschweig. The HyMountEcos project was funded through the European Facility for Airborne Research Transnational Access (EUFAR TA) project involving Polish and Czech research institutions.

The main objective of the project was to obtain APEX hyperspectral data of the Polish and Czech part of the Karkonosze Mountains. Simultaneously to airborne data acquisition, ground ASD FieldSpec 3 and GPS measurements of large homogenous polygons $(10 \times 10 \mathrm{~m})$ were conducted. Spectral characteristics (ASD FieldSpec 3) were used for atmospheric correction. The data processing procedures at VITO were realised in January 2013.
The reference data used for classification are maps of nonforest (Wojtuń et al. 2004) and forest communities ${ }^{8}$ in vector format, obtained from the Karkonosze National Park Administration. Based on forest and non-forest maps, visual analysis of the APEX data and ground photos, the patterns of the most characteristic, homogenous polygons were selected for classification and calibration.

\section{Methods}

For the classification of vegetation communities, it was necessary to develop and test the classification algorithm of high resolution hyperspectral APEX data, to determine the suitability of airborne imagery to identify the vegetation in the Karkonosze National Park, and finally, to prepare a map of the distribution of selected communities in this area (Figure 2).

A supervised learning method of boundary decision - the Support Vector Machines (SVM), implemented in the ENVI 5 software - was used in the study. This method identifies the class associated with each pixel and employs optimization algorithms to locate the optimal boundaries between classes (Huang et al. 2002). Originally, this algorithm was used for the classification of binary data, but later scientists proposed solutions that enable continuous data to be classified using the so-called method of "one against one" or "one against all" (Benediktsson \& Waske 2009). It is widely used for pattern recognition, for example isolated handwritten digit recognition, object recognition, speaker identification, face detection in images, text categorization etc. (Burges 1998; Huang et al. 2002). SVM provides good classification results - even noisy bands are successfully detected (Camps-Valls et al. 2004). The algorithm is quite time-consuming, especially for a large number of classes, but still a lot faster than neural networks (Dixon \& Candade 2008).

The APEX images and vector data were processed in ENVI 5 software. The maps of forest and non-forest vegetation allowed polygons of each class to be reselected into 2 separate vector layers (classification and validation patterns were saved as *.roi files). About 400 pixels were selected randomly from the groundrevised polygons as a training set and double this -800 pixels - for the validation patterns (Pal \& Mather 2006).

${ }^{8}$ The map was prepared by the Bureau for Forest Management and Geodesy, Brzeg (http://www.buligl.pl/web/biuro-urzadzania-lasu-en/home). 


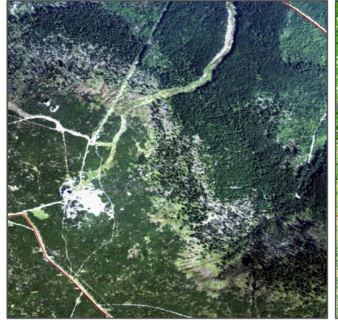

(a)

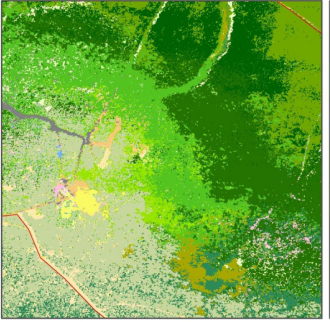

(b)

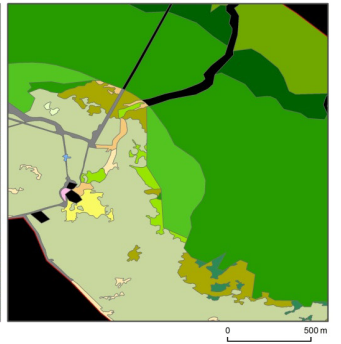

(c)

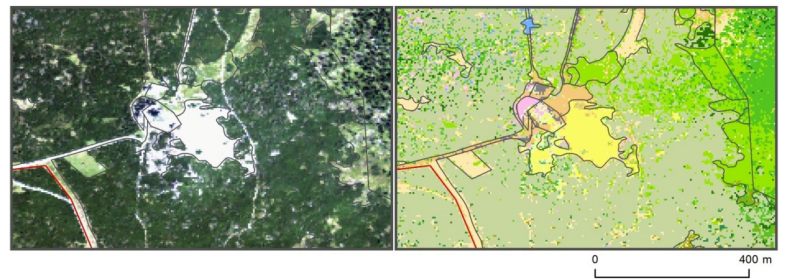

(d)

(e)

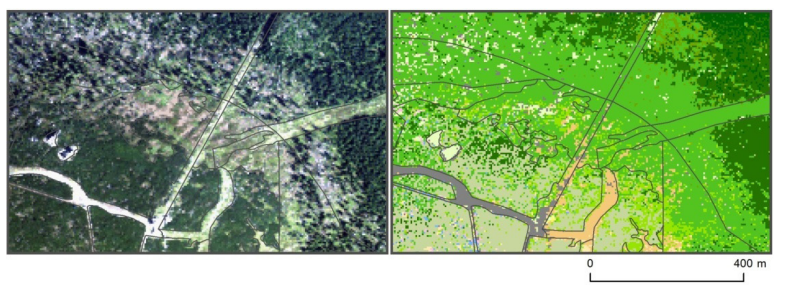

(f)

(g)
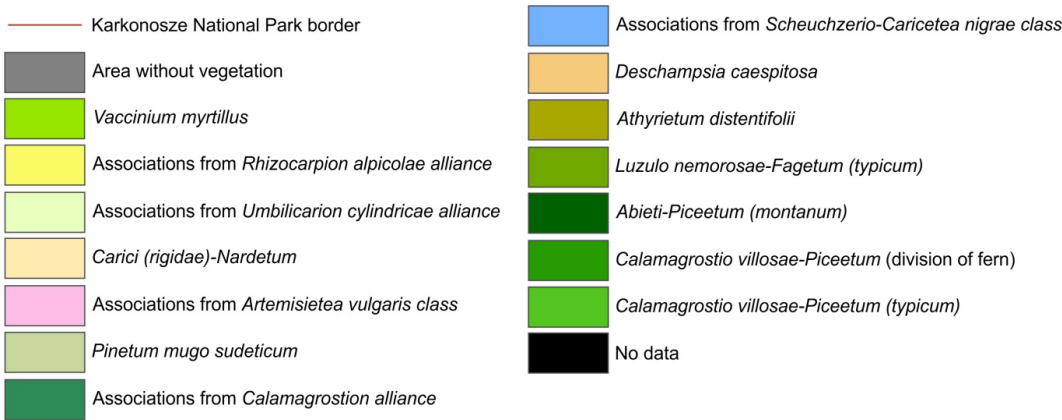

(h)

Figure 3. a) APEX RGB composition, similar to the natural colours (bands: $0.6403,0.5473,0.4614 \mu m$ ), b) the post-classification map of vegetation, c) corresponding map of vegetation acquired from the field mapping by Wojtuń et al. 2004, d) part of the hyperspectral imagery with a vector layer, e) part of the post-classification image with Rhizocarpion alpicolae alliance, f) hyperspectral imagery with a vector layer, g) part of the post-classification image with Athyrietum distentifolii association, h) legend

All 288 APEX bands and the test patterns were used for the image classification. Different kernel types - linear, polynomial, radial basis function and sigmoid - were tested in the SVM procedure. Finally, the linear kernel type was chosen because of the best results. The classification image was generated following the classification. For an accuracy assessment, the standard tools of ENVI procedures (post classification, confusion matrix, using ground truth) procedures were applied, which could analyse overall accuracy, kappa coefficient, user and producer accuracy and error matrix.

\section{Results}

The acquired classification results showed a significant potential for preliminary terrain recognition prior to traditional, phytosociological mapping. The post classification images (Figure 3) and statistics are acceptable (Table 1, 2). The classified image is much more detailed compared to the field map acquired during field research. It is important that some parts of the Szrenica area were excluded from touristic activity and all succession processes were shown in the APEX data (Figure $3 \mathrm{~d}, \mathrm{e}, \mathrm{h}$ ). The overall accuracy was $79.13 \%$ and the kappa coefficient, showing the gradual reduction of errors in comparison to the classification carried out at random, was 0.77 .

The best results in this study were observed for associations from the Rhizocarpion alpicolae alliance - the producer accuracy was $99.06 \%$, and the user accuracy was $99.76 \%$. The class was homogenous, the test polygons represented by a high reflectance of electromagnetic radiation (Figure $3 d, e, h$ ). Most 
Table 1. Classification error matrix (\%) of the following classes: \#1 area without vegetation; \#2 Vaccinium myrtillus; \#3 associations from Rhizocarpion alpicolae alliance; \#4 associations from Umbilicarion cylindricae alliance; \#5 Carici (rigidae)-Nardetum; \#6 associations from Artemisietea vulgaris class; \#7 Pinetum mugo sudeticum; \#8 associations from Calamagrostion alliance; \#9 associations from Scheuchzerio-Caricetea nigrae class; \#10 Deschampsia caespitose; \#11 Athyrietum distentifolii; \#12 Luzulo nemorosae-Fagetum (typicum); \#13 Abieti-Piceetum (montanum); \#14 Calamagrostio villosae-Piceetum (division of fern); \#15 Calamagrostio villosae-Piceetum (typicum)

\begin{tabular}{|c|c|c|c|c|c|c|c|c|c|c|c|c|c|c|c|}
\hline Class & \#1 & \#2 & \#3 & \#4 & \#5 & \#6 & \#7 & \#8 & \#9 & \#10 & \#11 & \#12 & \#13 & \#14 & \#15 \\
\hline \#1 & $\mathbf{8 3 . 8}$ & 0.0 & 0.2 & 3.3 & 0.0 & 2.2 & 0.0 & 0.0 & 2.3 & 1.8 & 5.8 & 0.0 & 0.0 & 0.0 & 0.0 \\
\hline \#2 & 1.2 & $\mathbf{7 7 . 2}$ & 0.0 & 0.0 & 2.4 & 0.0 & 0.7 & 0.0 & 4.7 & 2.6 & 8.2 & 0.0 & 0.0 & 0.0 & 12.8 \\
\hline \#3 & 0.0 & 0.0 & $\mathbf{9 9 . 1}$ & 0.0 & 0.0 & 0.0 & 0.0 & 0.0 & 0.0 & 0.3 & 0.0 & 0.0 & 0.0 & 0.0 & 0.0 \\
\hline \#4 & 0.0 & 0.2 & 0.0 & $\mathbf{9 3 . 3}$ & 0.0 & 4.4 & 0.0 & 0.0 & 0.0 & 0.3 & 14.7 & 0.2 & 0.2 & 0.0 & 0.2 \\
\hline \#5 & 0.7 & 1.3 & 0.0 & 0.0 & $\mathbf{8 9 . 4}$ & 0.0 & 0.0 & 0.0 & 2.3 & 0.5 & 0.0 & 0.0 & 0.0 & 0.0 & 0.4 \\
\hline \#6 & 0.5 & 0.2 & 0.0 & 0.0 & 0.0 & $\mathbf{8 9 . 1}$ & 0.0 & 0.0 & 4.7 & 0.0 & 0.0 & 0.0 & 0.0 & 0.0 & 0.0 \\
\hline \#7 & 0.2 & 1.1 & 0.0 & 1.1 & 1.9 & 0.0 & $\mathbf{9 9 . 1}$ & 0.0 & 2.3 & 0.0 & 0.0 & 0.0 & 0.0 & 0.2 & 1.7 \\
\hline \#8 & 0.0 & 0.0 & 0.0 & 0.0 & 3.4 & 0.0 & 0.0 & $\mathbf{9 3 . 2}$ & 0.0 & 0.0 & 0.0 & 0.0 & 0.0 & 0.0 & 0.2 \\
\hline \#9 & 0.0 & 0.0 & 0.0 & 0.0 & 0.0 & 0.0 & 0.0 & 0.0 & $\mathbf{8 3 . 7}$ & 0.0 & 0.0 & 0.0 & 0.0 & 0.0 & 0.2 \\
\hline \#10 & 11.4 & 0.0 & 0.7 & 0.0 & 2.9 & 4.4 & 0.0 & 0.0 & 0.0 & $\mathbf{7 3 . 2}$ & 3.6 & 0.0 & 0.0 & 0.0 & 0.2 \\
\hline \#11 & 0.0 & 0.0 & 0.0 & 0.0 & 0.0 & 0.0 & 0.2 & 6.6 & 0.0 & 0.0 & $\mathbf{0 . 2}$ & 0.0 & 0.0 & 0.0 & 0.4 \\
\hline \#12 & 0.0 & 0.0 & 0.0 & 0.0 & 0.0 & 0.0 & 0.0 & 0.0 & 0.0 & 0.0 & 0.0 & $\mathbf{7 7 . 0}$ & 28.6 & 0.0 & 0.0 \\
\hline \#13 & 0.0 & 0.0 & 0.0 & 0.0 & 0.0 & 0.0 & 0.0 & 0.0 & 0.0 & 0.0 & 0.0 & 22.6 & $\mathbf{6 5 . 6}$ & 0.2 & 0.0 \\
\hline \#14 & 0.0 & 0.0 & 0.0 & 1.1 & 0.0 & 0.0 & 0.0 & 0.2 & 0.0 & 0.0 & 0.0 & 0.0 & 5.5 & $\mathbf{9 9 . 1}$ & 2.3 \\
\hline \#15 & 2.3 & 19.9 & 0.0 & 1.1 & 0.0 & 0.0 & 0.0 & 0.0 & 0.0 & 21.3 & 67.5 & 0.2 & 0.0 & 0.4 & $\mathbf{8 1 . 6}$ \\
\hline Total & 100.0 & 100.0 & 100.0 & 100.0 & 100.0 & 100.0 & 100.0 & 100.0 & 100.0 & 100.0 & 100.0 & 100.0 & 100.0 & 100.0 & 100.0 \\
\hline
\end{tabular}

Table 2. The user and producer accuracies for 15 classes

\begin{tabular}{|c|c|c|c|}
\hline \multicolumn{2}{|c|}{ Class } & User accuracy (\%) & Producer accuracy (\%) \\
\hline$\# 1$ & area without vegetation & 83.60 & 90.48 \\
\hline$\# 2$ & Vaccinium myrtillus & 77.24 & 73.85 \\
\hline$\# 3$ & associations from Rhizocarpion alpicolae alliance & 99.06 & 99.76 \\
\hline$\# 4$ & associations from Umbilicarion cylindricae alliance & 93.33 & 54.55 \\
\hline$\# 5$ & Carici (rigidae)-Nardetum & 89.37 & 96.35 \\
\hline$\# 6$ & associations from Artemisietea vulgaris class & 89.13 & 94.25 \\
\hline$\# 7$ & Pinetum mugo sudeticum & 99.14 & 94.86 \\
\hline$\# 8$ & associations from Calamagrostion alliance & 93.17 & 96.22 \\
\hline$\# 9$ & associations from Scheuchzerio-Caricetea nigrae class & 83.72 & 97.3 \\
\hline$\# 10$ & Deschampsia caespitosa & 73.23 & 76.86 \\
\hline$\# 11$ & Athyrietum distentifolii & 0.24 & 3.23 \\
\hline$\# 12$ & Luzulo nemorosae-Fagetum (typicum) & 77.02 & 77.32 \\
\hline$\# 13$ & Abieti-Piceetum (montanum) & 65.63 & 69.44 \\
\hline$\# 14$ & Calamagrostio villosae-Piceetum (division of fern) & 99.14 & 92.74 \\
\hline$\# 15$ & Calamagrostio villosae-Piceetum (typicum) & 81.59 & 45.56 \\
\hline
\end{tabular}

communities were classified with a similarly high accuracy, except for one class, Athyrietum distentifolii. The smallest user accuracy was $65.63 \%$ - the highest between 80 and $100 \%$; most classes achieved producer accuracy at around $90 \%$ (Table 1). These accuracies for fourteen classes are good results. This is supported by the results of analyses on the DAIS 7915 in the
Tatras, carried out for 42 classes, where the user accuracy was between $36.0 \%$ and $100 \%$ and producer accuracy between 81.5 and $100 \%$ (Zagajewski 2010).

The lowest producer accuracy observed in the classification was $34.05 \%$ and the highest $100 \%$, whereas the user accuracies ranged from $32.06 \%$ to $100 \%$. The worst results 
at the Szrenica Mount and surroundings were observed for Athyrietum distentifolii - the producer accuracy was $0.24 \%$ and the user accuracy was $3.23 \%$. This was caused by heterogeneity, mixture of various plants shrouding the spectral profile of the Athyrietum distentifolii compound with a different reflectance in the community, representing the class, and a large number of mixels ${ }^{9}$. Additionally, in recent years near the Szrenica Mount, fern leaves are being eaten by insects, which means that for subsequent years the leaves do not rise, and thus the community is replaced by another - in this case, by Calamagrostio villosaePiceetum (typicum) (Figure $3 \mathrm{f}, \mathrm{g}, \mathrm{h}$ ).

The results of the SVM classification change for different types of kernel (Pal \& Mather 2004; Huang et al. 2002). In this study for the polynomial kernel the overall accuracy was $68.57 \%$, kappa coefficient was 0.66 , for radial basis function $-68.26 \%$ and 0.66 and the worst for the sigmoid kernel $-60.01 \%$ and 0.55 .

\section{Conclusions}

Hyperspectral data can be used to obtain detailed information about vegetation, for example, identifying plant communities Very good results were acquired for the classification using all APEX bands, even though some of them were noisy, due to e.g. water vapour in the air $(1.4 \mu \mathrm{m}-1.45 \mu \mathrm{m})$. We proved that selection of the appropriate kernel type is crucial for the final classification results. In our case the best results were obtained using the linear kernel. We can conclude that the Support Vector Machines

${ }^{9}$ mixels - "mixed pixels". classifier, combined with APEX hyperspectral data, is a powerful tool for the identification of plant communities. The only concern was the classification of small plant communities because of the number of pixels required for the algorithm to work.

The development of methods for the automated processing and classification of data is particularly important in this time of easy access to hyperspectral data, e.g. Hyperion or EnMAP (Zagajewski 2010). Because of the large amount of information and its numerous applications, especially environment monitoring, it is very useful in administrating protected areas, such as the Karkonosze National Park, which has been exposed to the effects of acid rain which has greatly affected the state of current vegetation in the area. It can also be a supporting tool for traditional mapping techniques (Szymura et. al 2007).

\section{Acknowledgements}

The authors wish to thank the European Facility for Airborne Research Transnational Access (EUFAR TA) which funded the flight campaign and the Foundation of the University of Warsaw for financial support for the field campaign during the HyMountEcos project. Special thanks to the German Space Agency for execution of the flight and VITO for obtaining and processing the APEX data, to the Czech and Polish Karkonosze National Parks for the necessary data and help in leading the research and to the Institute of Geography and Spatial Organisation, Charles University in Prague and the University of Warsaw, who were involved in the whole project.

\section{References}

Benediktsson, JA \& Waske, B 2009, 'Next Frontier for Classification Tools: SVM and Beyond, 3rd HYPER-I-NET School on Hyperspectral Imaging', Data Processing: from hyperspectral images to information, Pavia. Available from: http://hyperinet.multimediacampus.it/images/Benediktsson. pdf>. [8-11 September 2009].

Biuro Urządzenia Lasu i Geodezji Leśnej 2009. Available from: <http://www.buligl.pl/web/biuro-urzadzania-lasu-en/home>.

Burges, CJC 1998, 'A tutorial on support vector machines for pattern recognition, data mining and knowledge discovery', Kluwer Academic Publishers, vol. 2, pp. 121-167.

Camps-Valls, G, Gomez-Chova, L, Calpe-Maravilla, J, MartinGuerrero, JD, Soria-Olivas, E, Alonso-Chorda, L \& Moreno, J 2004, 'Robust support vector method for hyperspectral data classification and knowledge discovery', IEEE Transactions on Geoscience and Remote Sensing, vol. 42, no. 7, pp. 1530-1542.

Chan, JCW, Beckers, P, Spanhove, T \& Vanden Borre, T 2012, 'An evaluation of ensemble classifiers for mapping Natura 2000 heathland in Belgium using spaceborne angular hyperspectral (CHRIS/Proba) imagery', International Journal of Applied Earth Observation and Geoinformation, vol. 18, pp. 13-22.

Dalponte, M, Bruzzone, L \& Gianelle, D 2008, 'Fusion of hyperspectral and LIDAR Remote sensing data for classification of complex forest areas', IEEE Transactions On Geoscience and Remote Sensing, vol. 46, no. 5, pp. $1416-1427$.

Delalieux, S, Somers, B, Haest, B, Kooistra, L, Mücher, CA \& Vanden Borre, J 2010, 'Monitoring heathland habitat status using hyperspectral image classification and unmixing', Proceedings of the 2nd Whispers on Hyperspectral Image and Signal Processing: Evolution in Remote Sensing (WHISPERS), IEEE GRSS, University of Iceland, Reykjawik, pp. 50-54.
Dixon, B \& Candade, N 2008, 'Multispectral landuse classification using neural networks and support vector machines: one or the other, or both?', International Journal of Remote Sensing, vol. 29, no. 4, pp. 1185-1206.

Goetz, AFH 2009, 'Three decades of hyperspectral remote sensing of the Earth: A personal view', Remote Sensing of Environment, vol. 113, pp. S5-S16.

Gualtieri, JA \& Cromp, RF 1998, Support vector machines for hyperspectral remote Sensing classification, Proceedings of the 27th AIPR Workshop', Advances in Computer Assisted Recognition, pp. 221-232.

Huang, C, Davis, LS \& Townshend, JRG 2002, 'An assessment of support vector machines for land cover classification', International Journal of Remote Sensing, vol. 23 pp. 725749.

Itten, KI, Dell'Endice, F, Hueni, A, Kneubühler, M, Schläpfer, D, Odermatt, D, Seidel, D, Huber, S, Schopfer, J, Kellenberger, T, Bühler, Y, D'Odorico, P, Nieke, J, Alberti, E \& Meuleman, K 2008, 'APEX - the hyperspectral ESA airborne prism experiment', Sensors, vol. 8, pp. 6235-6259.

Kokaly, RF, Despain, DG, Clark, RN \& Livo, KE 2003, 'Mapping vegetation in Yellowstone National Park using spectral feature analysis of AVIRIS data', Remote Sensing of Environment, vol. 84, pp. 437-456.

Olesiuk, D, Bachmann, M, Habermeyer, M, Heldens, W \& Zagajewski, B 2009, 'Crop classification with neural networks using airborne hyperspectral imagery', Roczniki Geomatyki, vol. VII, no. 32, pp. 107-112.

Pal, M \& Mather, PM 2004, 'Assessment of the effectiveness of support vector machines for hyperspectral data', Future Generation Computer Systems, vol. 20, no. 7, pp. 12151225.

Pal, M \& Mather, PM 2006, 'Some issues in the classification of DAIS hyperspectral data'. International Journal of Remote Sensing, vol. 27, pp. 2895-2916. 
Szymura, TH, Dunajski, A, Aman, I, Makowski, M, \& Szymura, M 2007, 'The spatial pattern and microsites requirements of Abies alba natural regeneration in the Karkonosze Mountains', Dendrobiology, vol. 58, pp. 51-57.

Wojtuń, B, Żołnierz, L \& Raj, A 2004, 'Nowy operat ochrony ekosystemów nieleśnych Karkonoskiego Parku Narodowego, Geoekologické problémy Krkonoš', Opera Corcontica, vol. 41, pp. 560-567.

Zagajewski, B 2010, 'Ocena przydatności sieci neuronowych i danych hiperspektralnych do klasyfikacji roślinności Tatr Wysokich' (Assessment of neural networks and Imaging
Spectroscopy for vegetation classification of the High Tatras), Teledetekcja Środowiska, vol. 43.

Zagajewski, B \& Sobczak, M 2003, 'Field remote sensing techniques for mountains vegetation investigation', Proceedings of the 3rd EARSeL Workshop on Imaging Spectroscopy, Oberpfaffenhofen, pp. 580-596.

Zagajewski, B, Kozłowska, A, Krówczyńska, M, Sobczak, M \& Wrzesień, M 2005, 'Mapping high mountain vegetation using hyperspectral data'. EARSeL eProceedings, vol. 4, no. 1 , pp. $70-78$. 